OPEN ACCESS

Edited by:

María Del Mar Guerrero,

Murcian Institute for Agrarian and

Food Research and Development

(IMIDA), Spain

Reviewed by:

Jose Antonio Pascual,

Consejo Superior de Investigaciones Cientificas (CSIC), Spain

Josefina Contreras,

Universidad Politécnica de

Cartagena, Spain

${ }^{*}$ Correspondence:

Sally A. Miller

miller.769@osu.edu

Specialty section

This article was submitted to

Waste Management in

Agroecosystems,

a section of the journal

Frontiers in Sustainable Food Systems

Received: 23 December 2020

Accepted: 24 February 2021

Published: 25 March 2021

Citation:

Khadka RB and Miller SA (2021)

Synergy of Anaerobic Soil

Disinfestation and Trichoderma spp. in

Rhizoctonia Root Rot Suppression.

Front. Sustain. Food Syst. 5:645736.

doi: 10.3389/fsufs.2021.645736

\section{Synergy of Anaerobic Soil Disinfestation and Trichoderma spp. in Rhizoctonia Root Rot Suppression}

\author{
Ram B. Khadka and Sally A. Miller* \\ Department of Plant Pathology, The Ohio State University College of Food, Agricultural and Environmental Sciences, \\ Wooster, $\mathrm{OH}$, United States
}

Potential synergy between anaerobic soil disinfestation (ASD) and Trichoderma spp. in suppression of Rhizoctonia root rot in radish was evaluated. A split-plot design with three replications was used; main plots were Trichoderma harzianum T22, Trichoderma asperellum NT25 and a non-Trichoderma control. Subplots were ASD carbon sources wheat bran, molasses, chicken manure, and mustard greens and two non-amended controls: anaerobic (covered and flooded) and aerobic (not covered or flooded). Carbon sources and Rhizoctonia solani inoculant were mixed with soil, placed in pots, and flooded, followed by drenching Trichoderma spore suspensions and sealing the pots in zip-lock bags. After 3 weeks, bags were removed, soil was aired for 1 week and radish "SSR-RR-27" was seeded. Rhizoctonia root rot severity and incidence were lowest in radish plants grown in ASD-treated soil amended with wheat bran, molasses, or mustard greens across all Trichoderma treatments. Disease severity was lower in radish plants treated with NT25 than with T22 or the non-Trichoderma control across all ASD treatments, and in radish grown in ASD-treated soil amended with wheat bran plus NT25 compared to ASD-wheat bran or NT25 alone. Rhizoctonia solani populations were significantly reduced by ASD treatment regardless of carbon source, while Trichoderma populations were not affected by ASD treatment with the exception of ASD-mustard greens. The interactions of either Trichoderma isolate and ASD with most carbon sources were additive, while T22 with ASD-molasses and NT25 with ASD-wheat bran interactions were synergistic in reducing disease severity. One interaction, T22 with ASD-chicken manure was antagonistic. Enhancement of ASD efficacy in suppressing soilborne diseases such as Rhizoctonia root rot by additional soil amendment with Trichoderma spp. during the process appears to be dependent on both Trichoderma isolate and ASD carbon source.

Keywords: reductive soil disinfestation, biocontrol, soilborne pathogen, radish, anaerobic soil disinfestation, Trichoderma spp., Rhizoctonia root rot

\section{INTRODUCTION}

Rhizoctonia solani is an important soilborne plant pathogen that causes diseases including root rot, crown rot, damping off, and foliar blight in numerous economically important plant species (AjayiOyetunde and Bradley, 2018). Rhizoctonia solani frequently produces highly resilient sclerotia, has a wide host range, and is composed of diverse groups (anastomosis groups), making it difficult to 
manage (Ohkura et al., 2009). These diseases are particularly challenging in vegetable production systems because of the succulent nature of the plants, lack of resistant cultivars, and limited fungicide efficacy. Emerging and young seedlings are particularly susceptible to $R$. solani (Jaiswal et al., 2019).

Anaerobic soil disinfestation (ASD) is a promising tool to manage soilborne diseases in vegetable crops (Shennan et al., 2014; Testen and Miller, 2019). The broad-spectrum efficacy of ASD against nematodes, plant pathogens, and weeds is attractive to growers (Butler et al., 2012). Anaerobic soil disinfestation (ASD) treatment includes the incorporation of easily decomposable carbon sources into the soil, irrigation to saturation, and covering with plastic to create anaerobic conditions (Butler et al., 2014). During decomposition of carbon sources, microbial activities increase and organic acids and volatile compounds are released, which results in significant changes in soil $\mathrm{pH}$, metal ion availability, and microbial community composition (Momma et al., 2005; Momma, 2015). These changes and their interaction with other soil and environmental factors have negative impacts on plant pathogens in soil (van Agtmaal et al., 2015). However, considerable increase in fungal diversity and microbial activity in soil after ASD treatment have been reported (Zhao et al., 2018). Microbial community shifts in ASDtreated soils are particularly driven by carbon source inputs (Mazzola et al., 2018; Testen and Miller, 2018).

Trichoderma spp. are widely studied and commonly used beneficial fungi (Benítez et al., 2004; Singh et al., 2014; Harman et al., 2019). They have multifaceted benefits in crop production including growth promotion (Altomare et al., 1999), disease suppression (Vinale et al., 2009; Widmer, 2014), soil remediation (Vankar and Bajpai, 2008; Tripathi et al., 2013), and nutrient mobilization in soil (Khalili et al., 2012). Trichoderma spp. suppress soilborne diseases through mechanisms including mycoparasitism, production of antibiotics, induced systemic resistance, and competitive rhizosphere colonization (Benítez et al., 2004). Some Trichoderma isolates have been reported to grow normally up to $37-40^{\circ} \mathrm{C}$ (Pedreschi et al., 1997; Poosapati et al., 2014), producing stress protectant sugars such as trehalose, mannose, and raffinose under high temperatures to adapt to extreme conditions (Poosapati et al., 2014). Trichoderma isolates have been shown to grow in conditions of extremely high and low pH (Chovanec et al., 2005) and salinity (GalHemed et al., 2011) by utilizing diversified secondary metabolic processes. Chovanec et al. (2005) also reported that some Trichoderma isolates survived under oxygen-deficient conditions using fermentative metabolism.

Several Trichoderma isolates naturally parasitize fungal sclerotia, which leads to a substantial mortality of these structures in soil (Geraldine et al., 2013). Production of cell wall-degrading enzymes by Trichoderma spp., stimulated in the presence of fungal sclerotia, is responsible for their mortality in soil (Geraldine et al., 2013). Anaerobic soil disinfestation (ASD) treatment has been shown to increase both endemic and artificially inoculated populations of Trichoderma harzianum in soil (Shrestha et al., 2019). However, they found no added benefit of combining T. harzianum or Trichoderma asperellum inoculation and ASD in increasing mortality of sclerotia of Sclerotium rolfsii.

The present study was designed to determine if carbon source differentially affects the survival of two Trichoderma species isolates during ASD, and if the isolates act synergistically with ASD to suppress Rhizoctonia root rot of radish caused by R. solani. Trichoderma asperellum NT25 is a native isolate of Nepal effective in reducing Rhizoctonia root rot disease caused by $R$. solani in radish and clubroot caused by Plasmodiophora brassicae in mustard greens (unpublished data). We tested T. asperellum NT25, isolated from the mid-hill region of Nepal in 2016 and commercial isolate T. harzianum T22 in this study. T22 is a commercially well-established strain of Trichoderma developed by protoplast fusion of two T. harzianum isolates, which are reported as benomyl-resistant, rhizosphere-competent, and suppressive to several fungal and oomycete pathogens (Sivan and Harman, 1991).

\section{MATERIALS AND METHODS}

\section{Fungal Isolates and Inoculum Preparation}

Rhizoctonia solani SAM-RS-33.1-2016 isolated from radish and previously determined to be pathogenic on radish was used. The pathogen was retrieved from long term storage on twiceautoclaved winter rye seed by culturing on acidified potato dextrose agar medium (aPDA; 39 g PDA (IBI Scientific, Dubuque, IA), $750 \mu 1$ lactic acid per L).

Inoculum was prepared in soil potato mix (Ko, 1971) with minor modifications. One hundred twenty-five milliliter of sandy soil was mixed with $13 \mathrm{~g}$ peeled and chopped potato and $25 \mathrm{ml}$ distilled water in a $250 \mathrm{ml}$ Erlenmyer flask. The mixture was autoclaved $\left(121^{\circ} \mathrm{C}, 16 \mathrm{PSI}\right.$ for $\left.30 \mathrm{~min}\right)$ twice at $24 \mathrm{~h}$ intervals. Pieces $\approx 1-2 \mathrm{~cm}$ in size were cut from the edge of one 7-dayold $R$. solani culture on PDA medium per flask and added to the soil-potato mixture. The mixture was agitated every 3 days by hand. After 21 days, the R. solani-inoculated soil-potato mixture was stirred thoroughly with a glass rod, vortexed briefly, poured onto paper towels and allowed to dry in a laminar flow hood overnight. The dry mixture was passed through a $2 \mathrm{~mm}$ mesh sieve followed by a $0.59 \mathrm{~mm}$ mesh sieve. The inoculum was stored at $4^{\circ} \mathrm{C}$. Soil was inoculated at the rate of $0.6 \mathrm{~g}$ per liter of soil.

Trichoderma harzianum T22 was applied as the commercial formulation of the biocontrol product RootShield-WP (BioWorks, Victor, New York, USA; Sivan and Harman, 1991). Trichoderma asperellum NT25 maintained on silica gel (Samuels, 2015) was grown on PDA plates for 7 days at $25 \pm 2{ }^{\circ} \mathrm{C}$ with a $12 \mathrm{~h}$ light/dark cycle. Ten milliliters of sterile water was poured in each Trichoderma culture plate and a sterile plastic inoculating loop was used to dislodge the conidia. The suspensions were placed into $5 \mathrm{ml}$ test tubes and vortexed briefly, then passed through four layers of sterilized cheesecloth to remove hyphae and mycelia. Conidia were counted with a hemocytometer and the final concentrations were adjusted to $10^{5}$ conidia $\mathrm{ml}^{-1}$ by addition of sterile deionized water. 


\section{Soil Attributes}

Certified organic field soil was collected from Badger Farm, OSU CFAES Wooster Campus in November 2016 and sealed in plastic bags. Soil was dried, ground, homogenized, and screened through $1 \mathrm{~cm}$ mesh before storing at $10^{\circ} \mathrm{C}$ until use. Soil pH was 6.8 , organic matter was $1.7 \%$ and cation exchange capacity was 10.7 (med/100 g; Spectrum Analytic Inc., Washington Court House, $\mathrm{OH})$.

\section{Evaluation of ASD and Trichoderma for Suppression of $\boldsymbol{R}$. solani}

Experiments were established in a split plot design in which Trichoderma isolates were the main plot treatments and carbon sources were subplot treatments. Soils were treated with ASD and/or Trichoderma in $10-\mathrm{cm}$-diameter $(350 \mathrm{ml})$ plastic pots with drainage holes in the bottom. Carbon sources were raw chicken manure, wheat bran, molasses, and mustard greens biomass (Table 1). Wheat bran, chicken manure, and mustard greens biomass were mixed with soil before placement in the pots. Molasses was mixed with an equal volume of water and poured onto soil in pots. Mustard greens "Southern Giant Curled" seeds (Thiram ${ }^{\circledR}$ treated seed, Seedway, Hall, NY, USA) were sown into 50-cell plug trays containing Baccto Professional Grower Mix (Houston, TX) and grown for 30-40 days under greenhouse conditions programmed at $25^{\circ} \mathrm{C}$ and 14 -h light. Plants were uprooted and washed in tap water followed by chopping and maceration of entire plants in a blender (Waring Commercial Blender, Waring Commercial, Torrington, CT). Mustard greens biomass was applied at $10 \mathrm{~g}$ dry matter $\mathrm{kg}^{-1}$ soil equivalent to $\approx 100 \mathrm{~g}$ fresh biomass $\mathrm{kg}^{-1}$ soil, and chicken manure, wheat bran and molasses were applied at $10 \mathrm{~g} \mathrm{~kg}^{-1}$ soil.

Pots were flooded with $\approx 300 \mathrm{ml}$ tap water and allowed to drain for about $2 \mathrm{~h}$. One IRIS (Indicator of Reduction in Soils; Rabenhorst, 2012) tube, a $1.3 \mathrm{~cm}$ diameter polyvinyl chloride (PVC) pipe painted with iron oxide paint (Rabenhorst, 2008), was inserted into the soil through a guide hole in the center of each pot to measure reducing conditions in the soil during

TABLE 1 | Characteristics of carbon sources for anaerobic soil disinfestation used in the experiments.

\begin{tabular}{lccl}
\hline $\begin{array}{l}\text { Carbon } \\
\text { source }\end{array}$ & Rate ${\mathbf{~ ( ~} \mathbf{~ k g}^{\mathbf{z}}}^{-1}$ soil) & C:N ratio & Source \\
\hline $\begin{array}{l}\text { Raw chicken } \\
\text { manure }\end{array}$ & 10 & 9.5 & $\begin{array}{l}\text { Poultry Research Farm, } \\
\text { OSU CFAES Wooster } \\
\text { Campus }\end{array}$ \\
Wheat bran & 10 & 17 & $\begin{array}{l}\text { The Mennel Milling } \\
\text { Company, Fostoria, OH }\end{array}$ \\
Molasses & 10 & 81 & $\begin{array}{l}\text { Golden Barrel Blackstrap } \\
\text { Molasses, Good Food, Inc., } \\
\text { Honey Brook, PA }\end{array}$ \\
$\begin{array}{l}\text { Mustard greens } \\
\text { biomass }\end{array}$ & 10 & 12 & $\begin{array}{l}\text { Southern Giant Curled" } \\
\text { grown for } 30-40 \text { days in } \\
\text { greenhouse }\end{array}$ \\
\hline
\end{tabular}

${ }^{z}$ Mustard greens were used on a dry matter basis equivalent to $100 \mathrm{~g}$ fresh weight. treatment. For treatments including T. asperellum NT25, a 525 $\mu l$ suspension of $1.5 \times 10^{6}$ conidia $\mathrm{ml}^{-1}$ of the isolate was pipetted into each pot. Rootshield WP (6\% v/v suspension) was inoculated at $1 \mathrm{ml} \mathrm{kg}^{-1}$ soil. Pots were then double-bagged with $(946 \mathrm{ml})$ zipper plastic bags $\left(\right.$ Ziploc $^{\circledR}$, S.C. Johnson and Son, Racine, WI), sealed and incubated in growth chambers for 25 days on a $12 \mathrm{~h}$ light $/ 30^{\circ} \mathrm{C}-12 \mathrm{~h}$ dark $/ 25^{\circ} \mathrm{C}$ cycle. Soil samples $(\approx 100 \mathrm{~g})$ were collected in paper bags immediately after removal of the plastic bags for identification and enumeration of microorganisms. Two non-amended control treatmentsanaerobic and aerobic controls were also included. Anaerobic control pots received $300 \mathrm{ml}$ water and were sealed within plastic bags, while aerobic control pots received $300 \mathrm{ml}$ water but not sealed.

\section{Soil Attributes After ASD Treatment}

Soil moisture percentage affects soil reducing conditions, therefore soil gravitational moisture was determined. Soil samples of $\approx 50 \mathrm{~g}$ were placed in paper envelopes immediately after removal of plastic bags from ASD-treated and anaerobic control pots, as well as aerobic control pots, and soil weights were recorded. Then soil samples were dried at $60^{\circ} \mathrm{C}$ in a hot air oven for $48 \mathrm{~h}$ and final weights recorded. The soil moisture percentage was calculated by using the following formula:

$$
\frac{(\text { Weight of the soil before drying }- \text { Weight after drying) }}{\text { Soil weight before drying }} \times 100
$$

Soil reducing conditions in each pot were determined based on the loss of iron oxide paint on IRIS tubes inserted in soil in pots prior to treatment. The percentage of paint removal from pipes was assessed visually using a grid after rods were removed from the pots.

\section{Enumeration of Trichoderma in ASD-Treated Soil}

Additional soil samples (total $\approx 50 \mathrm{~g}$ ) removed from three locations in each pot using a metal spatula immediately after termination of ASD and control treatments were dried at room temperature for 1 week in a paper envelope. Soil samples were then broken up by pounding the envelope with a rubber mallet followed by thorough mixing by gently shaking the envelope. Five grams of soil were taken from each sample and mixed with $45 \mathrm{ml}$ sterile deionized water and vortexed briefly. One hundred microliters of this suspension were added to $900 \mu \mathrm{l}$ sterile water in a $1.2 \mathrm{ml}$ well of a 96 deep well plate (Uniscience Corporation, Miami Lakes, FL). The $10^{-2}$ suspension was serially diluted to $10^{-4}$ and $200 \mu \mathrm{l}$ suspensions from the $10^{-3}$ and $10^{-4}$ dilutions were spread-plated onto $85 \mathrm{~mm}$ plates containing Trichoderma selective medium (Askew and Laing, 1993). Total Trichoderma spp. colonies were counted 10 days after plating and colony forming units (CFU) $\mathrm{g}^{-1}$ soil were calculated (Foght and Aislabie, 2005). 


\section{Quantitative PCR Assay for R. solani Population Quantification in ASD-Treated Soil}

Rhizoctonia solani populations in soil were quantified by using a SYBR Green-based qPCR assay (Lievens et al., 2006) targeting the $R$. solani rDNA internal transcribed spacer (ITS) region. Soil DNA was extracted using the DNeasy ${ }^{\circledR}$ PowerSoil ${ }^{\circledR}$ Kit (Qiagen Hilden, Germany) following the manufacturer's instructions. The qPCR assay was performed in a total volume of $20 \mu \mathrm{l}$ as follows: $2 \mu \mathrm{l}$ of target DNA, $10 \mu \mathrm{l}$ SYBR Green premix Ex Taq $(2 \times$, Takara Bio Inc., Otsu, Shiga, Japan), $1 \mu \mathrm{l}$ of $10 \mu \mathrm{M}$ forward primer (ST1-AGTGTTATGCTTGGTTCCACT), $1 \mu 1$ of $10 \mu \mathrm{M}$ reverse primer (ITS4-TCCTCCGCTTATTGATAT GC), and $6 \mu$ l nuclease free water. The PCR cycle was set at $95^{\circ} \mathrm{C}$ for $2 \mathrm{~min}$, followed by $95^{\circ} \mathrm{C}$ for $10 \mathrm{~s}$ and $60^{\circ} \mathrm{C}$ for $34 \mathrm{~s}$, for 40 cycles in a thermal cycler (Bio-Rad C100 Touch Thermal Cycler, Bio-Rad, Hercules, CA, USA). A melting curve analysis was generated at the end of the qPCR assay by monitoring fluorescence from the PCR solution during heating to $95^{\circ} \mathrm{C}$, cooling to $60^{\circ} \mathrm{C}$, and slowly heating to $95^{\circ} \mathrm{C}$ at $0.1^{\circ} \mathrm{C} \mathrm{s}^{-1}$ to evaluate the amplification specificity.

Genomic DNA was extracted from 7-day-old colonies of $R$. solani SAM-RS-33.1-2016 grown from a single hyphal tip on PDA at room temperature in the dark. After grinding the mycelia in liquid nitrogen, nucleic acid was extracted using a Promega Wizard genomic DNA purification kit (Promega Corporation, Madison, WI) following the manufacturer's instructions. Concentration and quality of the DNA were measured with a NanoDrop ND 1000 Spectrophotometer (NanoDrop Technologies, Wilmington, DE). Three subsets of

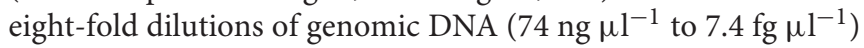
were also run in the same qPCR assay to generate a standard curve. ITS copy numbers were calculated by using the following formula (http://scienceprimer.com/copy-number-calculatorfor-realtime-PCR).

$$
\begin{aligned}
& \text { Number copies (molecules) } \\
& \qquad=\frac{X n g \times 6.0221 \times 10^{23} \text { molecules } / \text { mole }}{\left(N \times 660 \mathrm{~g} / \text { mole } \times 1 \times 10^{9} \mathrm{ng} / \mathrm{g}\right)}
\end{aligned}
$$

Where $X=$ amount of amplicon (ng), $N=$ length of ds DNA amplicon, which is $187 \mathrm{bp}$ for ST1, $660 \mathrm{~g} / \mathrm{mole}=$ average mass of 1 bp ds DNA.

\section{Rhizoctonia Root Rot Bioassay With Radish (Raphanus sativus L.)}

After ASD treatment, soil was allowed to air for 1 week to dissipate volatile compounds generated during the ASD process. Sixteen hybrid radish seeds cv. SSR-RR-27 (Seed Science, Salinas, CA) were planted per ASD-treated and control pot. Light irrigation was provided after sowing and pots were maintained in a growth chamber with the light and temperature regime mentioned above. Relative humidity of the chamber was maintained above $85 \%$ to facilitate infection. Plants were irrigated daily with tap water and no additional nutrients were supplied. Radish plants were uprooted 14 days after sowing and washed with tap water. Disease incidence was calculated by using the following formula: number of plants with symptoms $\times 100 /$ total number of plants assessed. Root rot severity was scored using a 0 to 4 scale, in which $0=0 \% ; 1=1-25 \% ; 2=26-50 \% ; 3=51-$ $75 \%$; and $4=76-100 \%$ root rot. The disease severity index was calculated by using the mid-point value of the percentage range according the following formula: [ $\Sigma$ (mid-point value $\times$ number of plants in category) $] \times 100 /$ number of plants assessed. After disease assessment, fresh whole plant biomass was measured.

The presence of $R$. solani in symptomatic roots was confirmed by plating samples (cut into $2-3 \mathrm{~cm}$ pieces that were surface disinfected with $0.8 \%$ sodium hypochlorite solution for $30 \mathrm{~s}$ and rinsed twice in sterilized distilled water) on aPDA medium.

\section{Data Analysis}

Differences between treatments were evaluated using the linear model function "lmr" in R Studio (R-3.2.5; RStudio Team, 2019) where exp (experimental run), exp:rep, and exp:rep:isolate were treated as random factors and isolate and isolate:carbon source were treated as fixed factors. All experiments were conducted twice. Data were subjected to the Shapiro-Wilk test for normality followed by the Bartlett test to check the homogeneity of variance before doing analysis of variance (ANOVA). Data that deviated from a normal distribution were either square root, log or arcsine-square-root transformed before proceeding with ANOVA. When there was a significant difference between treatment means, the Fisher test of least significant difference (LSD) was applied in the Agricolae package (De Mendiburu, 2016).

The Bliss independence model was applied assuming ASD carbon source and Trichoderma isolate act independently to suppress the root rot severity in radish (Yan et al., 2010; Willyerd et al., 2011; Xu et al., 2011). The combined effect of Trichoderma and ASD carbon source on root rot severity indicates the union of two probabilistically independent events. The combined effects $\left(\mathrm{F}_{\mathrm{UA}}\right)$ were calculated as the product of individual effects of Trichoderma isolates ( $\left.\mathrm{F}_{\mathrm{UA1}}\right)$ and ASD carbon source $\left(\mathrm{F}_{\mathrm{UA} 2}\right)$.

$$
\mathrm{F}_{\mathrm{UA}}=\mathrm{F}_{\mathrm{UA} 1} \times \mathrm{F}_{\mathrm{UA} 2}
$$

Where $\mathrm{F}_{\mathrm{UA}}$ is the remaining fraction of severity control relative to non-ASD and non-Trichoderma treatments (unaffected fraction of disease severity reduction, for example if disease severity reduction is $0.17, \mathrm{~F}_{\mathrm{UA}}$ will be $1-0.17=0.83$ ). According to the Bliss independence assumption, $\mathrm{F}_{\mathrm{UA}}$ is the expected effect of combined treatments; synergistic, additive and antagonistic relationships between the treatments were determined as follows:

1. If the observed combined effect of Trichoderma isolate and ASD-carbon source is equal to $\mathrm{F}_{\mathrm{UA}}$, the relationship is additive and there is no interaction between ASD-carbon sources and Trichoderma isolates

2. If the observed combined effect is greater than $\mathrm{F}_{\mathrm{UA}}$, the relationship is synergistic

3. If the observed combined effect is less than $F_{U A}$, the relationship is antagonistic. 


\section{RESULTS}

\section{Soil Attributes After ASD Treatment}

Soil inoculation with Trichoderma isolates had no effect on soil gravitational moisture after ASD (Table 2). Soil gravitational moisture percentage after ASD treatment was not significantly different between the anaerobic control soils and soils amended with mustard greens, molasses, wheat bran or chicken manure, ranging from 24.9 to $25.9 \%$ (anaerobic control). Soil reducing conditions as indicated by iron oxide paint loss from IRIS tubes were not significantly affected by Trichoderma inoculation $(P$ $=0.3$; Figure 1A). Reducing conditions developed in anaerobic control but not in aerobic control soils (Figure 1B). Paint loss was higher on IRIS tubes in ASD-treated soil regardless of type of amendment than in either non-amended control soil $(P=0.01)$. However, paint loss was higher on IRIS tubes in ASD-treated soils amended with molasses, mustard greens, or wheat bran than in soil amended with chicken manure. There were no significant differences in IRIS tube paint loss among soils amended with molasses, mustard greens, or wheat bran during ASD.

\section{Rhizoctonia Root Rot Incidence and Severity in ASD- and Trichoderma-Treated Soils}

Combined analysis of two independent experiments indicated that inoculation of soil with either of the Trichoderma isolates did not significantly $(P=0.5)$ reduce Rhizoctonia root rot incidence in radish plants compared to the non-inoculated controls across all ASD subplot treatments and controls (Figure 2A). However, Rhizoctonia root rot incidence was significantly lower $(P=$

TABLE 2 | Gravitational moisture percentage of soil after anaerobic soil disinfestation (ASD) with different carbon source amendments and with or without Trichoderma spp.

\begin{tabular}{lc}
\hline Isolate & Soil gravitational moisture $(\%)^{\mathbf{x y z}}$ \\
\hline Non-inoculated control & $25.0 \pm 3.8$ \\
T. harzianum T-22 & $24.8 \pm 2.3$ \\
T. harzianum NT25 & $24.2 \pm 4.8$ \\
$P$-value & 0.75 \\
Carbon source & \\
Aerobic control & $20.1 \pm 7.7 \mathrm{~b}$ \\
Anaerobic control & $25.9 \pm 0.6 \mathrm{a}$ \\
Mustard greens & $24.9 \pm 0.6 \mathrm{a}$ \\
Molasses & $25.6 \pm 0.9 \mathrm{a}$ \\
Chicken manure & $25.5 \pm 0.6 \mathrm{a}$ \\
Wheat bran & $25.8 \pm 0.8 \mathrm{a}$ \\
$P$-value & 0.004 \\
\hline
\end{tabular}

${ }^{x}$ Values in a column followed by different letters are significantly different at $P \leq 0.05$ according to Fisher's LSD test after square root transformation. The values after \pm indicate standard error of the mean.

${ }^{y}$ Average of two experiments each with three replications per treatment.

${ }^{z}$ Gravitational moisture percentage was determined by drying soil collected just after removal of plastic covering from ASD-treated or anaerobic control pots in an oven at $80^{\circ} \mathrm{C}$ for $48 \mathrm{~h}$.
0.01) in radish plants grown in molasses-, mustard greens, or wheat bran-amended, but not chicken manure-amended, ASD-treated soil than in radish plants grown in aerobic or anaerobic control soils across the Trichoderma main plot treatments (Figure 2B). Rhizoctonia root rot incidence was reduced by $36.6,31.7$, and $44.5 \%$ in ASD-treated soils amended with molasses, mustard greens and wheat bran, respectively, compared to the aerobic control across the Trichoderma main plot treatments (Supplementary Table 1). Specifically, ASD with molasses, mustard greens, or wheat bran carbon sources reduced root rot incidence significantly compared to the non-Trichoderma inoculated, aerobic control regardless of Trichoderma inoculant (none, T. asperellum or T. harzianum; Supplementary Table 2).

Rhizoctonia root rot severity was marginally significantly $(P=0.1)$ lower in radish plants grown in $T$. asperelluminoculated soil than in radish plants grown in ASD-treated soils without Trichoderma inoculum or inoculated with T. harzianum across all carbon sources (Figure 2C). Disease severity was reduced by $24.6 \%$ in $T$. asperellum-inoculated soils compared to aerobic control soils not inoculated with Trichoderma (Supplementary Table 3). Root rot severity was significantly lower $(P<0.001)$ in radish plants grown in molasses-, mustard greens-, or wheat bran-amended, ASD-treated soil than in radish plants grown in chicken manure-amended, ASD-treated soil and both aerobic and anaerobic control soils across the Trichoderma main plot treatments (Figure 2D). Mean disease severity ranged from $14.4 \%$ in radish plants grown in wheat bran-amended, ASD-treated soil to $58.1 \%$ in plants grown in anaerobic control soil, across all Trichoderma treatments (Supplementary Table 1). Disease severity was significantly lower in radish plants grown in ASD-treated soil amended with wheat bran, mustard greens (21.0\%) or molasses $(24.1 \%)$ than in ASD-treated soil amended with chicken manure $(48.7 \%)$ or in the aerobic $(49.3 \%)$ or anaerobic control soils. Rhizoctonia root rot severity was reduced by $51.1 \%, 57.4$, and $70.9 \%$ in ASD-treated soils amended with molasses, mustard greens and wheat bran, respectively, compared to the aerobic control across the Trichoderma main plot treatments (Supplementary Table 1). Disease severity was significantly lower $(P<0.001)$ in radish plants grown in soils treated with any combination of Trichoderma inoculum (T. asperellum or T. harzianum) and ASD with any carbon source except chicken manure compared to non-Trichodermainoculated aerobic control soils (Supplementary Table 2).

Synergy analysis using the Bliss independence model indicated that the combination responses between ASD treatment with any of the carbon sources and either of the two Trichoderma isolates were additive in suppressing Rhizoctonia root rot severity in radish, with the exception of T. asperellum with ASD-wheat bran, T. harzianum with ASD-molasses and T. harzianum with ASD-chicken manure (Table 3). The combination responses of T. harzianum inoculation with ASDmolasses and $T$. asperellum inoculation with ASD-wheat bran amendment were synergistic in suppressing Rhizoctonia root rot in radish. However, the combination response of T. harzianum inoculation with ASD-chicken manure was antagonistic toward suppression of disease severity in radish. 

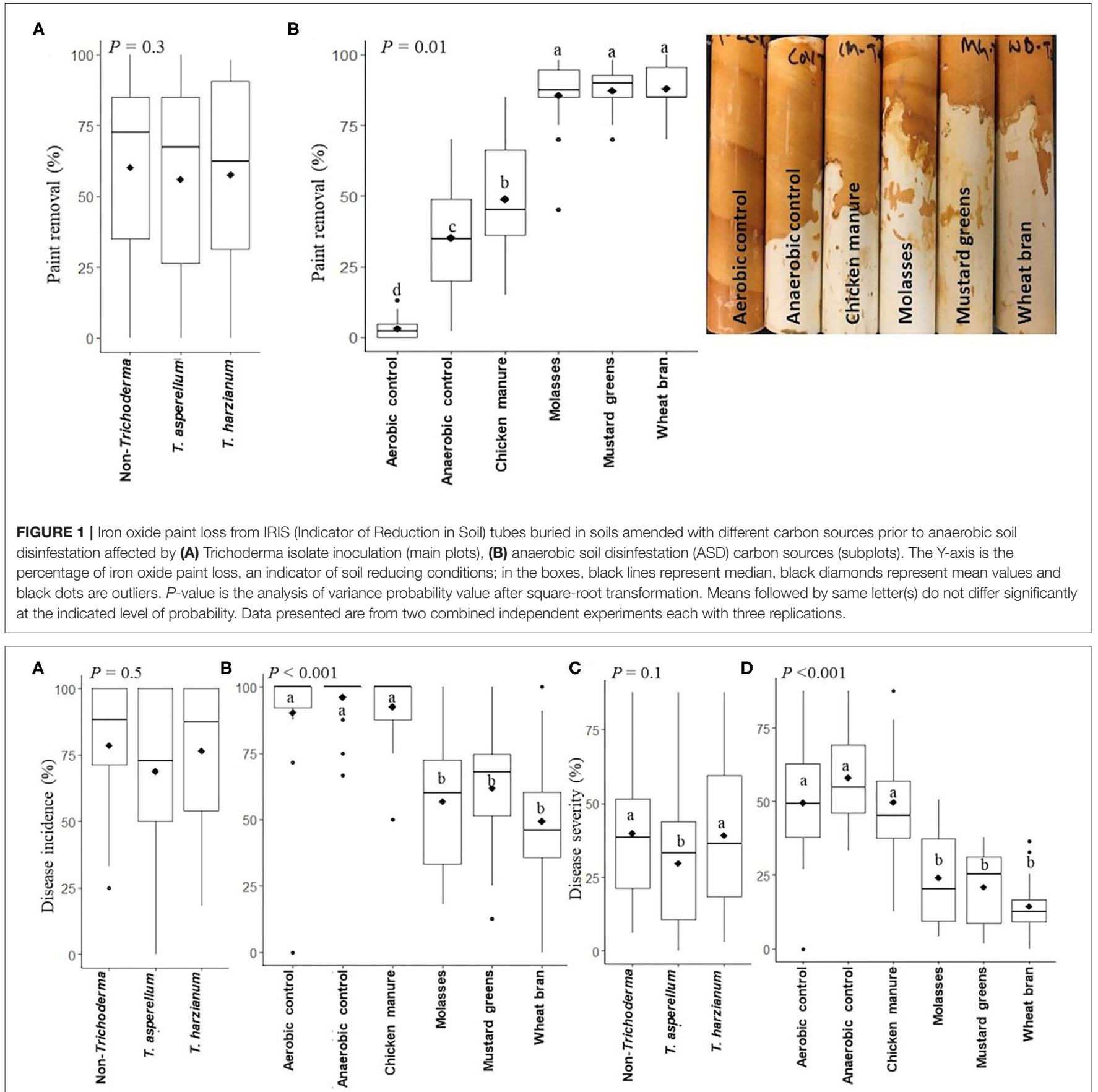

FIGURE 2 | Rhizoctonia root rot incidence (A,B) and severity (C,D) in radish affected by Trichoderma isolate inoculation (main plots) (A,C) and anaerobic soil disinfestation (ASD) carbon sources (subplots) (B,D) presented in box plots; black lines indicate median, black diamonds indicate mean values and black dots are outliers, $P$-value is the analysis of variance probability value after arcsine-square-root) transformation. Means followed by same letter(s) do not differ significantly at the indicated level of probability. Data presented are from two combined independent experiments each with three replications.

\section{Effect of Trichoderma and ASD Treatment on Radish Biomass}

Inoculation of soil prior to ASD with either Trichoderma isolate did not significantly $(P=0.2)$ affect the fresh biomass of radish plants grown in these soils across ASD subplot treatments (Figure 3A). However, soil treatment by ASD with chicken manure, mustard greens, or wheat bran amendments resulted in significantly $(P<0.001)$ higher radish biomass than ASD treatment of soils amended with molasses and the aerobic and anaerobic controls across 
TABLE 3 | Synergy and additivity analysis using the Bliss independence model between carbon source and Trichoderma spp. amendments in suppression of Rhizoctonia root rot in radish plants grown in anaerobic soil disinfestation (ASD)-treated soil.

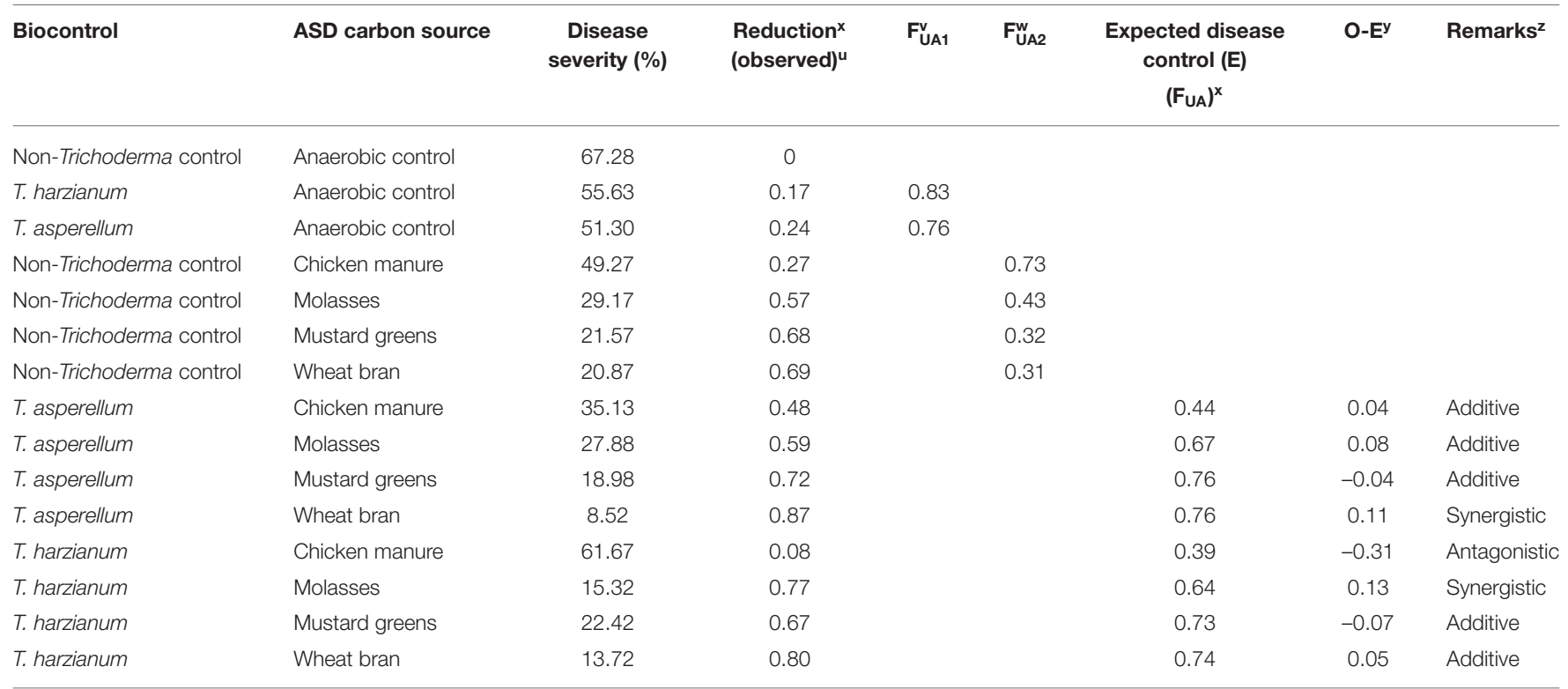

upercent reduction in Rhizoctonia root rot severity in radish compared to non-Trichoderma inoculated anaerobic control.

${ }^{v} F_{U A 1}=1$ - Percent reduction in Rhizoctonia root rot severity for Trichoderma isolate under anaerobic control conditions compared to non-Trichoderma inoculated anaerobic control.

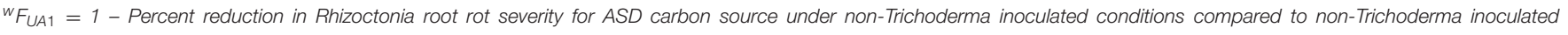
anaerobic control.

${ }^{x}$ Expected percent disease control (FUA $)=1-$ (FUA1forTrichodermaisolateunderanaerobicconditions $\times$ FUA2forASDcarbonsourceundernon-Trichodermainoculated conditions).

$y_{O} O$ - observed percent reduction in Rhizoctonia root rot severity, $E$ - expected percent disease control (FUA).

${ }^{z}$ Remarks: $O>E$ : synergistic, $O<E$ : antagonistic, otherwise: additive.

the Trichoderma inoculated and non-inoculated main plots (Figure 3B, Supplementary Table 1). The biomass of radish plants grown in ASD-treated soils amended with molasses was not different from that of radish grown in aerobic and anaerobic control soils and mustard greens-amended ASDtreated soils. Fresh radish plant biomass was increased by 156.4 , 110.8 , and $133.0 \%$ in ASD-treated soils amended with chicken manure, mustard greens and wheat bran, respectively, compared to the aerobic control across the Trichoderma inoculated and non-inoculated treatments (Supplementary Table 1). Fresh biomass was $173.9 \%$ higher in radish plants grown in nonTrichoderma inoculated, ASD-treated soil amended with chicken manure than in the non-Trichoderma inoculated, aerobic control (Supplementary Table 2). Fresh plant biomass was increased by $258.5,215.5$, and $246.1 \%$ in T. harzianum-inoculated soils amended with chicken manure, mustard greens, or wheat bran, respectively, then subjected to ASD, relative to the nonTrichoderma inoculated, aerobic control.

\section{Trichoderma spp. Populations in Soil After ASD Treatment}

Trichoderma spp. populations were highest $(P<0.001)$ in T. asperellum-inoculated ( $\left.\log 4.3 \mathrm{CFU}^{-1}\right)$ soils after ASD compared to $T$. harzianum-inoculated (log $3.1 \mathrm{CFU}$

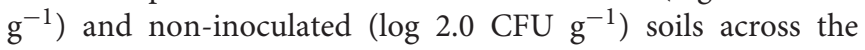
ASD-carbon source subplots (Figure 4A). Trichoderma spp. populations were not affected by flooding; populations in the aerobic and anaerobic controls were statistically similar across all Trichoderma inoculated and non-inoculated treatments (Figure 4B). Anaerobic soil disinfestation (ASD) with chicken manure, or wheat bran amendment did not reduce total Trichoderma spp. populations compared to the aerobic and anaerobic controls. However, molasses-amended ASD significantly $(P=0.05)$ reduced total Trichoderma spp. (log 2.7 CFU g $\mathrm{g}^{-1}$ ) in soil compared to the aerobic control (log 3.9 CFU $\mathrm{g}^{-1}$ ), and mustard greens-amended ASD (log $2.5 \mathrm{CFU}$ $\mathrm{g}^{-1}$ ) reduced total Trichoderma spp. populations compared to both controls.

\section{Rhizoctonia solani Populations in Soil After ASD and Trichoderma Treatment}

Rhizoctonia solani ITS gene copy numbers $\mathrm{g}^{-1}$ soil after ASD treatment were not significantly different in soils inoculated with $T$. harzianum or T. asperellum, or not inoculated, across the ASD carbon sources subplots $(P=0.5$; Figure 5A). However, ASD treatment of soils amended with wheat bran or mustard greens significantly $(P<0.0001)$ reduced $R$. solani populations compared to the aerobic and anaerobic controls and the chicken manure- and molasses-amended ASD treatments across the Trichoderma main plots (Figure 5B). Populations of $R$. solani were similar in aerobic and anaerobic control soils, while populations in chicken manure- or molasses-amended, ASDtreated soils were significantly reduced compared to the aerobic control only. 

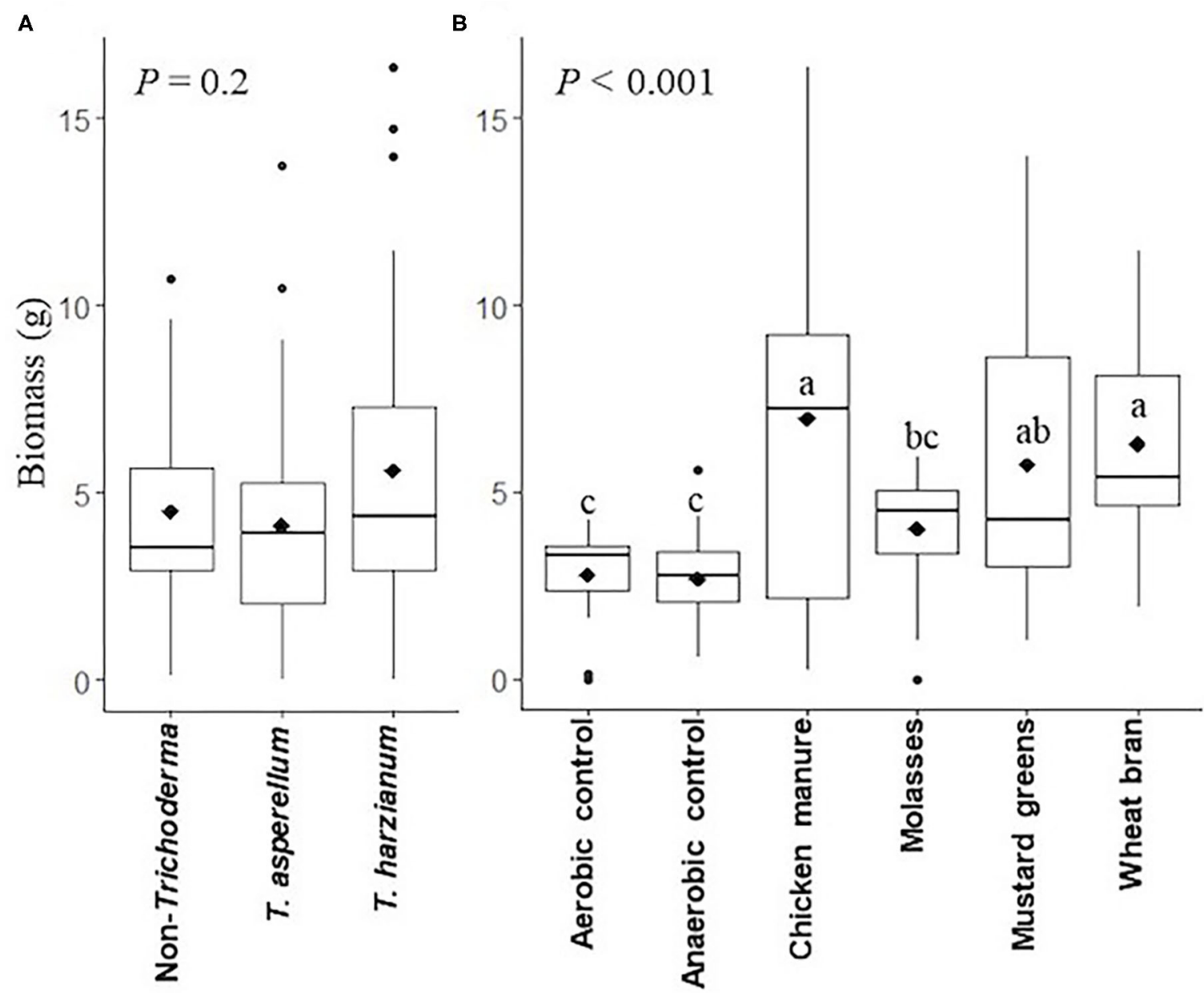

FIGURE 3 | Radish plant biomass (fresh weight) (A) as affected by Trichoderma isolate inoculation (main plots) and anaerobic soil disinfestation (ASD) carbon sources (subplots) (B) presented in box plots; black lines indicate median, black diamonds indicate mean values and black dots are outliers, $P$-value is the analysis of variance probability value. Means followed by same letter(s) do not differ significantly at $5 \%$ level of probability. Data presented are from two combined independent experiments each with three replications.

\section{DISCUSSION}

Diseases caused by $R$. solani are challenging to manage once the pathogen is established in soil because of its wide host range and production of environmentally resilient sclerotia (Cook et al., 2002). There are limited management options for these diseases. Anaerobic soil disinfestation and biological control are promising management tools that have no known negative environmental or health impacts (Harman, 2000; Rosskopf et al., 2015). No single method is entirely sufficient to control these diseases, therefore a combination of methods might be an effective strategy. The soil environment created by ASD is inhospitable for plant pathogens as a result of anaerobicity and the generation of toxic volatile and non-volatile fatty acids by soil microbial populations (Momma, 2015; Sanabria-Velazquez et al., 2020). It also improves crop growth by addition of soil nutrients (Paudel et al., 2018) and increases disease suppressiveness of the soil (Liu et al., 2019). Trichoderma spp. utilize several mechanisms to suppress soilborne diseases and to survive under a wide range of environmental conditions (Chovanec et al., 2005). If Trichoderma biocontrol agents can survive the toxic environment generated by ASD, the two tactics might be integrated to synergistically improve disease management in vegetable and other high value crop production systems.

The choice of carbon source plays a critical role in the efficacy of ASD. For instance, rice bran-amended ASD was comparatively less effective in suppressing root-knot severity in okra and eggplant than mustard cake- and molasses-amended ASD in Nepal (Khadka et al., 2019). The ASD carbon sources included in this study were selected based on their demonstrated efficacy in previous research (Butler et al., 2012; McCarty et al., 2014; Testen and Miller, 2018, 2019).

In this study, the Trichoderma populations were not reduced in ASD-treated soils when chicken manure, molasses, or wheat bran were used as carbon sources compared to the aerobic and/or anaerobic controls. This result provides strong evidence 
A

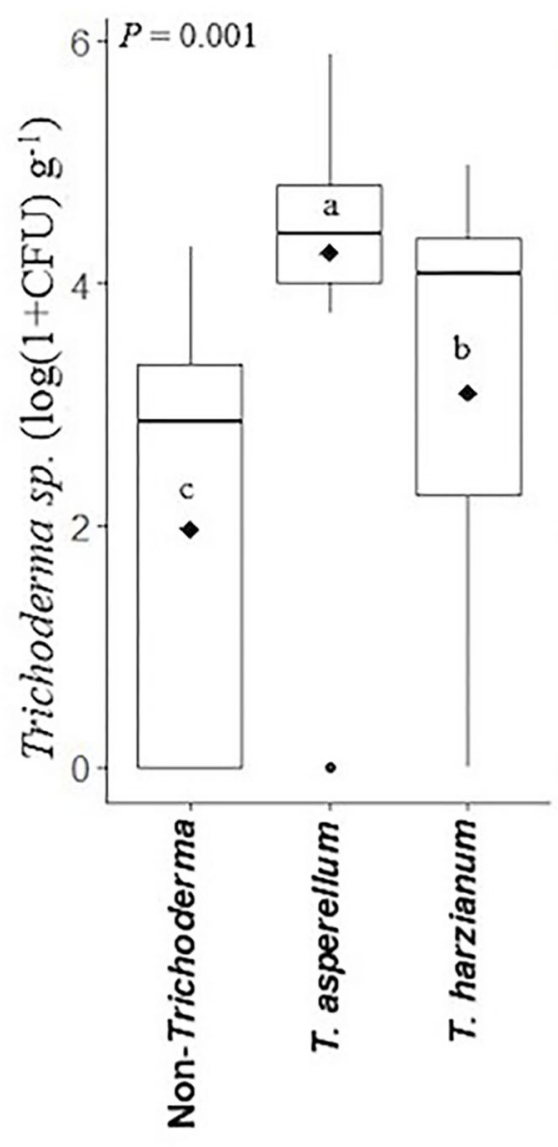

B

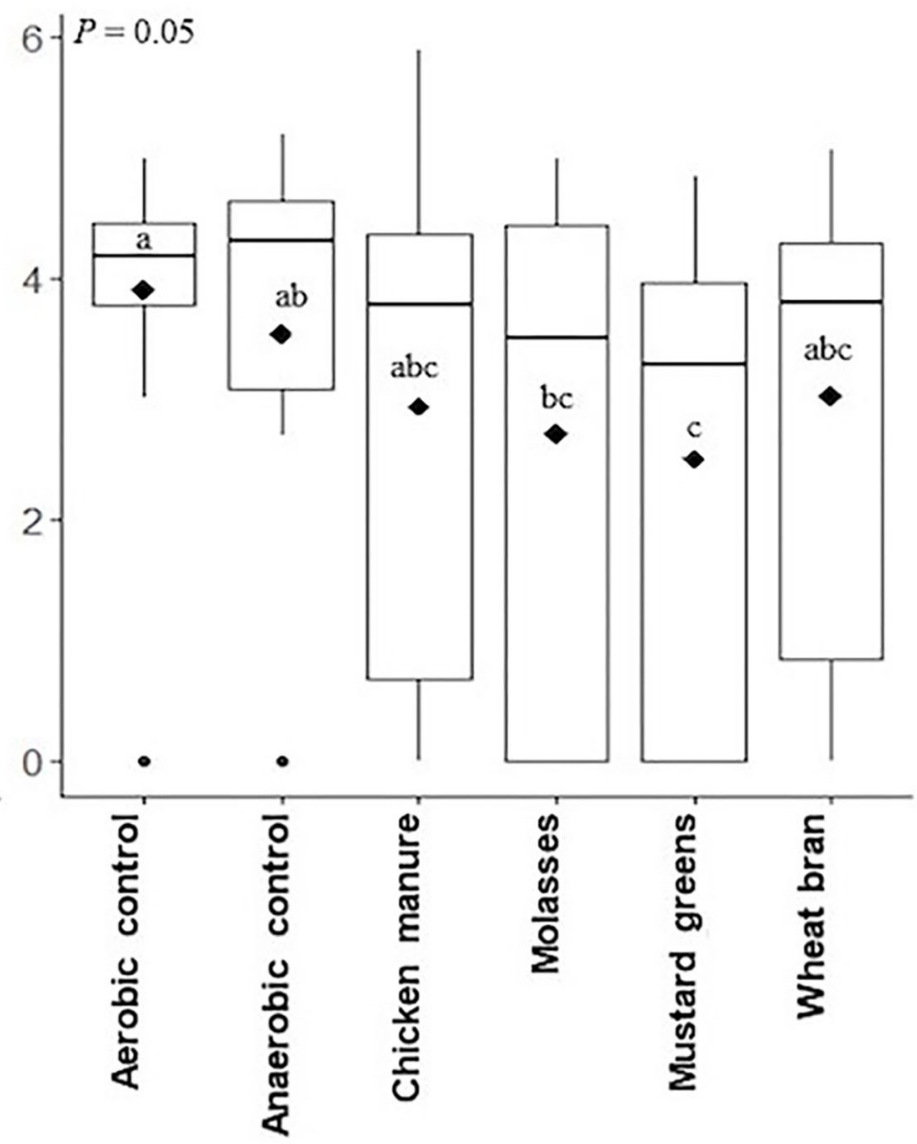

FIGURE 4 | Trichoderma populations (colony forming units $\mathrm{g}^{-1}$ soil) after ASD treatment affected by Trichoderma isolate inoculation (main plot) (A) and anaerobic soil disinfestation (ASD) carbon source subplots (B) presented in box plots; black lines indicate median black diamonds indicate mean values and black dots are outliers, $P$-value is the analysis of variance probability value after $1+\log$ transformation, CFU indicates colony forming unit, means followed by same letter(s) do not differ significantly at $5 \%$ level of probability. Data presented are from two combined independent experiments each with three replications.

that Trichoderma can survive under conditions generated during ASD. Previous reports have also demonstrated the survival of Trichoderma spp. during ASD (Lamers et al., 2010; Momma et al., 2013; Shrestha et al., 2019). Chovanec et al. (2005) reported that Trichoderma could survive under hypoxic conditions by utilizing fermentative metabolic oxygen. Similarly, Pedreschi et al. (1997) and Poosapati et al. (2014) showed that some Trichoderma isolates tolerated a wide range of $\mathrm{pH}$ and high temperatures either by using diversified secondary metabolic pathways or producing stress protectant sugars.

The lower population of Trichoderma spp. we observed in mustard greens-amended ASD-treated soil may be due to biocidal effects of isothiocyanates produced by most Brassica spp. when glucosinolates present in these plants are hydrolyzed (Sarwar and Kirkegaard, 1998). Isothiocyanates are chemically similar to methyl isothiocyanate, which is widely used for chemical fumigation (O’Malley, 2010). However, several reports indicate that Trichoderma spp. are tolerant of Brassica-based biofumigation of soil (Galletti et al., 2008; Berlanas et al., 2018). Isothiocyanates exist in a gaseous state (Clapp et al., 1959, p. 1) in soil and may be trapped when the soil is covered with plastic, increasing toxicity to soil microbes such as Trichoderma spp. and ensuring sufficient moisture for hydrolysis of glucosinolates compared to biofumigation, which is not covered.

The lower disease severity and incidence in radish plants grown in wheat bran-, mustard greens-, and molasses-amended ASD-treated soils compared to those grown in chicken manureamended ASD-treated and anaerobic and aerobic control soils are also supported by lower $R$. solani populations and higher soil reducing conditions in these treatments. In our studies, anaerobic conditions were increased by addition of carbon sources rather than soil moisture because gravitational soil moisture was not significantly different among covered and flooded (anaerobic) control soil and any carbon source-amended ASD-treated soil. However, reducing conditions were higher in all carbon source-amended ASD-treated soils than in the 

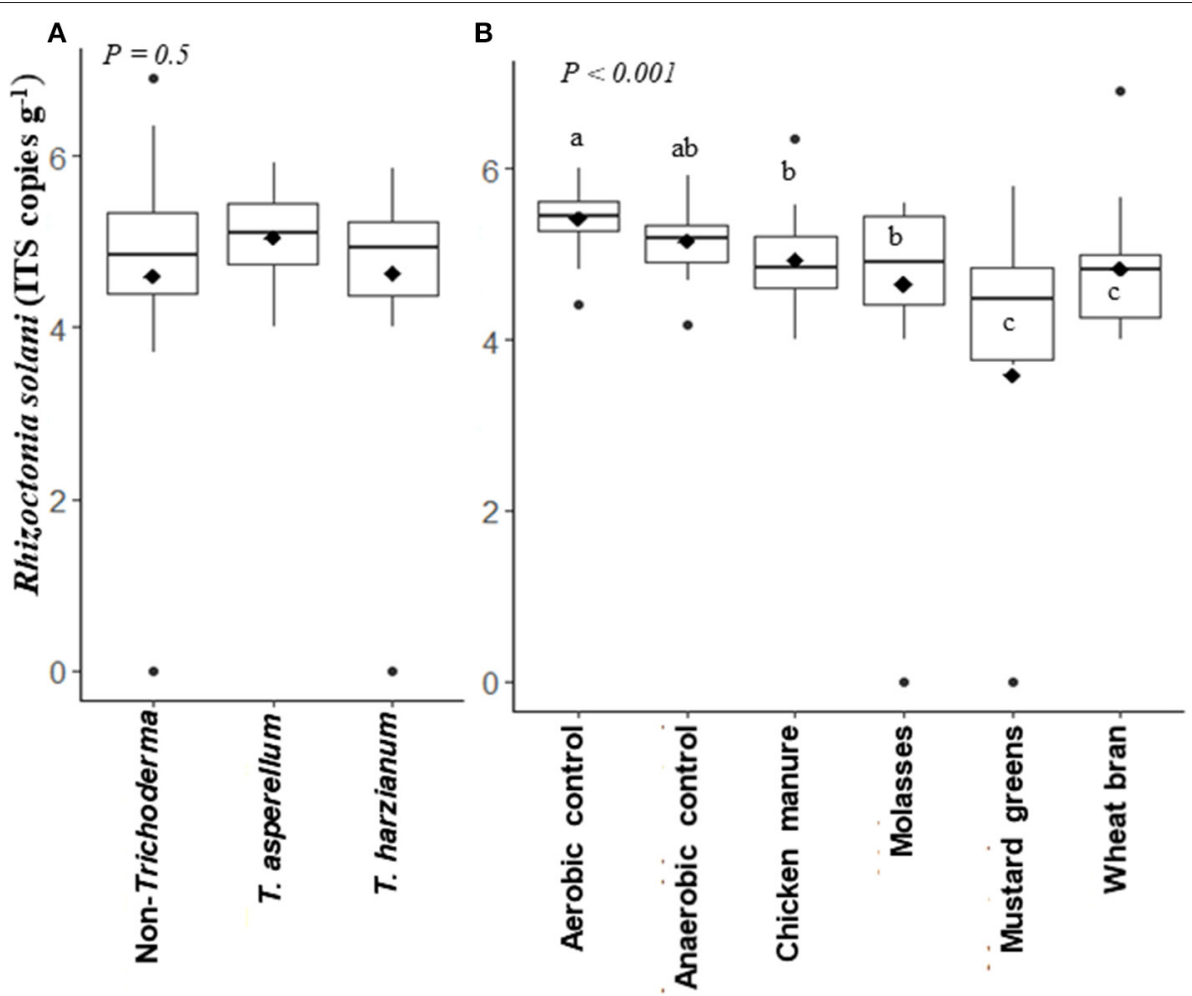

FIGURE 5 | Rhizoctonia solani populations (log ITS copy number $\mathrm{g}^{-1}$ soil) in soils affected by Trichoderma isolate inoculation (main plot) (A) and anaerobic soil disinfestation (ASD) carbon sources (subplots) (B) presented in box plots; black lines indicate median, black diamonds indicate mean values and black dots are outliers, $P$-value is the analysis of variance probability value after $1+\log$ transformation, CFU indicates colony forming unit means followed by same letter(s) do not differ significantly at $5 \%$ level of probability. Data presented are from two combined independent experiments each with three replications.

anaerobic control. Redox reactions under ASD conditions produce poorly oxidized compounds such as methane and ethylene gases, alcohol, and organic acids that are toxic to plant pathogens (Demirel and Yenigün, 2002; Merlin Christy et al., 2014). Plant pathogens including $R$. solani are aerobic microbes that require oxygen for survival and growth. Thus, hypoxic conditions may reduce the growth and multiplication of $R$. solani leading to reduced soil populations. Furthermore, ASD changes the soil microbial community composition, which leads to the domination of anaerobic microbes (Mazzola et al., 2018; Testen and Miller, 2018). Additionally, the reduced $R$. solani populations observed in this study might be due to low compatibility and poor competitiveness with anaerobic microbes under anaerobic conditions (Liu et al., 2019).

Rhizoctonia solani populations were not affected by Trichoderma inoculation of soils prior to ASD, but disease severity was lower in radish plants grown in T. asperellum-inoculated soil than in non-inoculated or T. harzianum-inoculated soil across all ASD treatments and the controls. Trichoderma spp. suppress Rhizoctonia diseases through different mechanisms, either directly killing pathogen propagules through hyperparasitism (Benhamou, 1993) or production of antibiotics (Ghisalberti and Sivasithamparam, 1991; Lorito, 1993; Tseng et al., 2008), and/or indirect mechanisms such as inducing systemic resistance in plants (Mayo et al., 2015) or competing for plant rhizosphere niches (Sivan and Harman, 1991). Reduced $R$. solani populations in Trichodermainoculated soils were not observed in this study, which indicates that indirect mechanisms may be responsible for the reduced disease severity in our T. asperellum-inoculated treatments.

Rhizoctonia root rot suppression was higher in radish plants grown in $T$. asperellum-inoculated soil compared to T. harzianum- or non-inoculated soil, this could be due to the presence of higher numbers of viable Trichoderma spores in T. asperellum-inoculated soil compared to T. harzianum and non-inoculated soil. In addition, Trichoderma isolates are known to vary in ability to suppress plant disease. For instance, Worasatit et al. (1994) tested fifty-four single spores isolates of Trichoderma koningii against $R$. solani in in-vitro and six isolates in in-planta and reported that only six isolates showed strong inhibition of pathogen growth in agar plate assays and only three isolates significantly suppressed Rhizoctonia root rot in wheat.

Few studies have been reported to date on the potential benefits of combining Trichoderma inoculation with ASD on soilborne disease suppression. Huang et al. (2016) reported a significant reduction in cucumber damping-off caused by $R$. solani in alfalfa-amended ASD plus T. harzianum T37 compared to alfalfa-amended ASD alone in the second season of 
cultivation after ASD treatment when T37 was inoculated after ASD treatment. In contrast, Shrestha et al. (2019) reported no additional benefits of Trichoderma spp. inoculation during ASD with a dry molasses/corn starch mixture as the carbon source on sclerotial mortality of $S$. rolfsi over ASD alone. We found that the interaction between ASD and Trichoderma in suppression of Rhizoctonia root rot was both Trichoderma isolate- and ASD carbon source-dependent. Most interactions in our study were additive, indicating neither beneficial nor detrimental effects of the combinations. However, the combinations of T. asperellum with ASD-wheat bran and T. harzianum with ASD-molasses were synergistic, resulting in greater disease suppression than with either alone. The combination of T. harzianum with ASDchicken manure was antagonistic, resulting in less root rot suppression than either alone. These results point to the need to optimize ASD carbon source and Trichoderma isolate choices in different pathosystems.

No effect of Trichoderma inoculation was observed on radish biomass; however differential impacts of ASD carbon sources on biomass were observed. Hewavitharana and Mazzola (2016) and Testen and Miller (2018) also reported differential impacts of ASD carbon sources on fresh plant biomass. In this study the chicken manure-amended ASD treatment resulted in higher plant biomass but not suppression of Rhizoctonia root rot, whereas ASD-molasses reduced disease severity but did not increase radish biomass. Only mustard greens- and wheat bran-amended ASD treatments both increased radish biomass and reduced root rot. Our results are supported by the observations of Testen and Miller (2018) that wheat branamended ASD reduced root rot severity and increased biomass in tomato, but ethanol and molasses amendments in ASD treatments reduced root rot severity but did not increase tomato biomass. Anaerobic soil disinfestation with wheat bran reduced Rhizoctonia root rot incidence and severity in radish and $R$. solani populations in soil, increased radish biomass and did not affect Trichoderma populations. Furthermore, T. asperellum NT25 interacted synergistically with ASD-wheat bran to reduce Rhizoctonia root rot severity. This study confirms the suitability

\section{REFERENCES}

Ajayi-Oyetunde, O. O., and Bradley, C. A. (2018). Rhizoctonia solani: taxonomy, population biology and management of Rhizoctonia seedling disease of soybean. Plant Pathol. 67, 3-17. doi: 10.1111/ppa. 12733

Altomare, C., Norvell, W. A., Björkman, T., and Harman, G. E. (1999). Solubilization of phosphates and micronutrients by the plant-growthpromoting and biocontrol fungus Trichoderma harzianum Rifai 1295-22. Appl. Environ. Microbiol. 65, 2926-2933. doi: 10.1128/AEM.65.7.2926-2933.1999

Askew, D. J., and Laing, M. D. (1993). An adapted selective medium for the quantitative isolation of Trichoderma species. Plant Pathol. 42, 686-690. doi: 10.1111/j.1365-3059.1993.tb01553.x

Benhamou, N. (1993). Hyphal interactions between Trichoderma harzianum and Rhizoctonia solani: ultrastructure and gold cytochemistry of the mycoparasitic process. Phytopathology 83:1062. doi: 10.1094/Phyto-83-1062

Benítez, T., Rincón, A. M., Limón, M. C., and Codón, A. C. (2004). Biocontrol mechanisms of Trichoderma strains. Int. Microbiol. 7, 249-260.

Berlanas, C., Andrés-Sodupe, M., López-Manzanares, B., Maldonado-González, M. M., and Gramaje, D. (2018). Effect of white mustard cover crop residue, soil chemical fumigation and Trichoderma spp. root treatment on of wheat bran as a preferred carbon source in ASD and suggests that ASD efficacy can be improved by addition of suitable Trichoderma isolates during treatment.

\section{DATA AVAILABILITY STATEMENT}

The raw data supporting the conclusions of this article will be made available by the authors, without undue reservation.

\section{AUTHOR CONTRIBUTIONS}

RK conducted the experiments and wrote the original draft. SM supervised RK for experimental design and revised the manuscript. Both authors contributed to the article and approved the submitted version.

\section{FUNDING}

This study was supported by the United States Agency for International Development under Cooperative Agreement No. AID-OAA-L-15-00001 to Virginia Tech and the Feed the Future Innovation Lab for Integrated Pest Management, and state and federal funds appropriated to The Ohio State University College of Food, Agricultural and Environmental Sciences.

\section{ACKNOWLEDGMENTS}

We thank Pierce A. Paul for guidance on data analysis and Francesca Rotondo for guidance on qPCR analysis. We also thank Michelle Jones, Maria-Soledad Benitez Ponce, Kaylee South, and Laura J. Chapin for comments and suggestions on the early drafts of the manuscript.

\section{SUPPLEMENTARY MATERIAL}

The Supplementary Material for this article can be found online at: https://www.frontiersin.org/articles/10.3389/fsufs. 2021.645736/full\#supplementary-material

black-foot disease control in grapevine. Pest Manag. Sci. 74, 2864-2873. doi: $10.1002 /$ ps.5078

Butler, D. M., Kokalis-Burelle, N., Albano, J. P., McCollum, T. G., Muramoto, J., Shennan, C., et al. (2014). Anaerobic soil disinfestation (ASD) combined with soil solarization as a methyl bromide alternative: vegetable crop performance and soil nutrient dynamics. Plant Soil 378, 365-381. doi: 10.1007/s11104-014-2030-z

Butler, D. M., Kokalis-Burelle, N., Muramoto, J., Shennan, C., McCollum, T. G., and Rosskopf, E. N. (2012). Impact of anaerobic soil disinfestation combined with soil solarization on plant-parasitic nematodes and introduced inoculum of soilborne plant pathogens in raised-bed vegetable production. Crop Protect. 39, 33-40. doi: 10.1016/j.cropro.2012. 03.019

Chovanec, P., Kalinák, M., Liptaj, T., Pronayová, N., Jakubík, T., Hudecová, D., et al. (2005). Study of Trichoderma viride metabolism under conditions of the restriction of oxidative processes. Can. J. Microbiol. 51, 853-862. doi: 10.1139/w05-075

Clapp, R. C., Long Jr., L., Dateo, G. P., Bissett, F. H., and Hasselstrom, T. (1959). The volatile isothiocyanates in fresh cabbage. J. Am. Chem. Soc. 81, 6278-6281. doi: $10.1021 / \mathrm{ja} 01532 \mathrm{a} 040$ 
Cook, R. J., Schillinger, W. F., and Christensen, N. W. (2002). Rhizoctonia root rot and take-all of wheat in diverse direct-seed spring cropping systems. Can. J. Plant Pathol. 24, 349-358. doi: 10.1080/07060660209507020

De Mendiburu, F. (2016). Agricolae: Statistical Procedures for Agricultural Research. $\mathrm{R}$ package Version 1.2-4. Available online at: https:/CRAN.R-project.org/ package $=$ agricolae

Demirel, B., and Yenigün, O. (2002). Two-phase anaerobic digestion processes: a review. J. Chem. Technol. Biotechnol. 77, 743-755. doi: 10.1002/jctb.630

Foght, J., and Aislabie, J. (2005). "Enumeration of soil microorganisms," in Monitoring and Assessing Soil Bioremediation, eds R. Margesin and F. Schinner (Berlin; Heidelberg: Springer-Verlag), 261-280. doi: 10.1007/3-540-28904-6_13

Gal-Hemed, I., Atanasova, L., Komon-Zelazowska, M., Druzhinina, I. S., Viterbo, A., and Yarden, O. (2011). Marine isolates of Trichoderma spp. as potential halotolerant agents of biological control for arid-zone agriculture. Appl. Environ. Microbiol. 77, 5100-5109. doi: 10.1128/AEM.00541-11

Galletti, S., Sala, E., Leoni, O., Burzi, P. L., and Cerato, C. (2008). Trichoderma spp. tolerance to Brassica carinata seed meal for a combined use in biofumigation. Biol. Control 45, 319-327. doi: 10.1016/j.biocontrol.2008.01.014

Geraldine, A. M., Lopes, F. A. C., Carvalho, D. D. C., Barbosa, E. T., Rodrigues, A. R., Brandão, R. S., et al. (2013). Cell wall-degrading enzymes and parasitism of sclerotia are key factors on field biocontrol of white mold by Trichoderma spp. Biol. Control 67, 308-316. doi: 10.1016/j.biocontrol.2013.09.013

Ghisalberti, E. L., and Sivasithamparam, K. (1991). Antifungal antibiotics produced by Trichoderma spp. Soil Biol. Biochem. 23, 1011-1020. doi: 10.1016/0038-0717(91)90036-J

Harman, G. E. (2000). Myths and dogmas of biocontrol changes in perceptions derived from research on Trichoderma harzinum T-22. Plant Dis. 84, 377-393. doi: 10.1094/PDIS.2000.84.4.377

Harman, G. E., Doni, F., Khadka, R. B., and Uphoff, N. (2019). Endophytic strains of Trichoderma increase plants' photosynthetic capability. J. Appl. Microbiol. 130, 529-546. doi: 10.1111/jam.14368

Hewavitharana, S. S., and Mazzola, M. (2016). Carbon source-dependent effects of anaerobic soil disinfestation on soil microbiome and suppression of Rhizoctonia solani AG-5 and Pratylenchus penetrans. Phytopathology 106, 1015-1028. doi: 10.1094/PHYTO-12-15-0329-R

Huang, X., Liu, L., Wen, T., Zhang, J., Wang, F., and Cai, Z. (2016). Changes in the soil microbial community after reductive soil disinfestation and cucumber seedling cultivation. Appl. Microbiol. Biotechnol. 100, 5581-5593. doi: 10.1007/s00253-016-7362-6

Jaiswal, A. K., Graber, E. R., Elad, Y., and Frenkel, O. (2019). Biochar as a management tool for soilborne diseases affecting early stage nursery seedling production. Crop Protect. 120, 34-42. doi: 10.1016/j.cropro.2019. 02.014

Khadka, R. B., Marasini, M., Rawal, R., Testen, A. L., and Miller, S. A. (2019). Effects of anaerobic soil disinfestation carbon sources on soilborne diseases and weeds of okra and eggplant in Nepal. Crop Protect. 135:104846. doi: 10.1016/j.cropro.2019.104846

Khalili, E., Sadravi, M., Naeimi, S., and Khosravi, V. (2012). Biological control of rice brown spot with native isolates of three Trichoderma species. Braz. J. Microbiol. 43, 297-305. doi: 10.1590/S1517-83822012000100035

Ko, W. H. (1971). A selective medium for the quantitative determination of Rhizoctonia solani in Soil. Phytopathology 61:707. doi: 10.1094/Phyto-61-707

Lamers, J. G., Runia, W. T., Molendijk, L. P. G., and Bleeker, P. O. (2010). Perspectives of anaerobic soil disinfestation. Acta Horticult. 277-283. doi: 10.17660/ActaHortic.2010.883.34

Lievens, B., Brouwer, M., Vanachter, A. C. R. C., Cammue, B. P. A., and Thomma, B. P. H. J. (2006). Real-time PCR for detection and quantification of fungal and oomycete tomato pathogens in plant and soil samples. Plant Sci. 171, 155-165. doi: 10.1016/j.plantsci.2006.03.009

Liu, L., Huang, X., Zhao, J., Zhang, J., and Cai, Z. (2019). Characterizing the key agents in a disease-suppressed soil managed by reductive soil disinfestation. Appl. Environ. Microbiol. 85:e02992-18. doi: 10.1128/AEM.02992-18

Lorito, M. (1993). Chitinolytic enzymes produced by Trichoderma harzianum richoderma harzianumes produced by a disease-suppressed soil managedPhytopathology 83:302. doi: 10.1094/Phyto-83-302

Mayo, S., Gutiérrez, S., Malmierca, M. G., Lorenzana, A., Campelo, M. P., Hermosa, R., et al. (2015). Influence of Rhizoctonia solani and Trichoderma spp. in growth of bean (Phaseolus vulgaris L.) and in the induction of plant defense-related genes. Front. Plant Sci. 6:685. doi: 10.3389/fpls.2015.00685

Mazzola, M., Muramoto, J., and Shennan, C. (2018). Anaerobic disinfestation induced changes to the soil microbiome, disease incidence and strawberry fruit yields in California field trials. Appl. Soil Ecol. 127, 74-86. doi: 10.1016/j.apsoil.2018.03.009

McCarty, D. G., Inwood, S. E. E., Ownley, B. H., Sams, C. E., Wszelaki, A. L., and Butler, D. M. (2014). Field evaluation of carbon sources for anaerobic soil disinfestation in tomato and bell pepper production in tennessee. HortScience 49, 272-280. doi: 10.21273/HORTSCI.49.3.272

Merlin Christy, P., Gopinath, L. R., and Divya, D. (2014). A review on anaerobic decomposition and enhancement of biogas production through enzymes and microorganisms. Renew. Sustain. Energy Rev. 34, 167-173. doi: 10.1016/j.rser.2014.03.010

Momma, N. (2015). Studies on mechanisms of anaerobicity-mediated biological soil disinfestation and its practical application. J. Gen. Plant Pathol. 81, 480-482. doi: 10.1007/s10327-015-0612-0

Momma, N., Kobara, Y., Uematsu, S., Kita, N., and Shinmura, A. (2013). Development of biological soil disinfestations in Japan. Appl. Microbiol. Biotechnol. 97, 3801-3809. doi: 10.1007/s00253-013-4826-9

Momma, N., Usami, T., Amemiya, Y., and Shishido, M. (2005). Factors involved in the suppression of Fusarium oxysporum $\mathrm{f}$. sp. lycopersici by soil reduction. Soil Microorgan. (Japan) 59, 27-33.

Ohkura, M., Abawi, G. S., Smart, C. D., and Hodge, K. T. (2009). Diversity and aggressiveness of Rhizoctonia solani and Rhizoctonia-like fungi on vegetables in New York. Plant Dis. 93, 615-624. doi: 10.1094/PDIS-93-6-0615

O'Malley, M. (2010). “The Regulatory evaluation of the skin effects of pesticides," in Hayes' Handbook of Pesticide Toxicology, 3rd Edn., ed R. Krieger (New York, NY: Academic Press), 701-787. doi: 10.1016/B978-0-12-374367-1.00028-8

Paudel, B. R., Gioia, F. D., Zhao, X., Ozores-Hampton, M., Hong, J. C., KokalisBurelle, N., et al. (2018). Evaluating anaerobic soil disinfestation and other biological soil management strategies for open-field tomato production in Florida. Renew. Agric. Food Syst. 35, 274-285. doi: 10.1017/S1742170518000571

Pedreschi, F., Aguilera, J. M., Agosin, E., and Martin, R. S. (1997). Induction of trehalose in spores of the biocontrol agent Trichoderma harzianum. Bioprocess Eng. 17, 317-322. doi: 10.1007/PL00008967

Poosapati, S., Ravulapalli, P. D., Tippirishetty, N., Vishwanathaswamy, D. K., and Chunduri, S. (2014). Selection of high temperature and salinity tolerant Trichoderma isolates with antagonistic activity against Sclerotium rolfsii. Springerplus 3:641. doi: 10.1186/2193-1801-3-641

Rabenhorst, M. C. (2008). Protocol for using and interpreting IRIS tubes. Soil Horizons 49, 74-77. doi: 10.2136/sh2008.3.0074

Rabenhorst, M. C. (2012). Simple and reliable approach for quantifying IRIS tube data. Soil Sci. Soc. Am. J. 76, 307-308. doi: 10.2136/sssaj2011.0267n

Rosskopf, E. N., Serrano-Pérez, P., Hong, J., Shrestha, U., Rodríguez-Molina, M. C., Martin, K., et al. (2015). “Anaerobic soil disinfestation and soilborne pest management," in Organic Amendments and Soil Suppressiveness in Plant Disease Management Soil Biology, eds M. K. Meghvansi and A. Varma (Cham: Springer), 277-305. doi: 10.1007/978-3-319-23075-7_13

RStudio Team (2019). Citing RStudio - RStudio Support. Available online at: http://www.rstudio.com/ and https://support.rstudio.com/hc/en-us/articles/ 206212048-Citing-Rstudio?mobile_site=true (accessed August 27, 2018)

Samuels, G. L. (2015). Trichoderma: Identification and Agricultural Applications. St. Paul, MN: The American Phytopathological Society (APS Press).

Sanabria-Velazquez, A. D., Testen, A. L., Khadka, R. B., Liu, Z., Xu, F., and Miller, S. A. (2020). Anaerobic soil disinfestation reduces viability of Sclerotinia sclerotiorum and S. minor sclerotia and root-knot nematodes in muck soils. Phytopathology 110, 795-804. doi: 10.1094/PHYTO-10-19-0386-R

Sarwar, M., and Kirkegaard, J. A. (1998). Biofumigation potential of brassicas. Plant Soil 201, 91-101. doi: 10.1023/A:1004333230899

Shennan, C., Muramoto, J., Lamers, J., Mazzola, M., Rosskopf, E. N., KokalisBurelle, N., et al. (2014). Anaerobic soil disinfestation for soil borne disease control in strawberry and vegetable systems: current knowledge and future directions. Acta Hortic. 1044, 165-175. doi: 10.17660/ActaHortic.2014.1044.20

Shrestha, U., Dee, M. E., Piya, S., Ownley, B. H., and Butler, D. M. (2019). Soil inoculation with Trichoderma asperellum, T. harzianum or Streptomyces griseoviridis prior to anaerobic soil disinfestation (ASD) does not increase 
ASD efficacy against Sclerotium rolfsii germination. Appl. Soil Ecol. 147:103383. doi: 10.1016/j.apsoil.2019.103383

Singh, A., Sarma, B. K., Singh, H. B., and Upadhyay, R. S. (2014). "Trichoderma: a silent worker of plant rhizosphere," in Biotechnology and Biology of Trichoderma, eds. V. K. Gupta, M. Schmoll, A. Herrera-Estrella, R. S. Upadhyay, I. Druzhinina, and M. G. Tuohy (Amsterdam: Elsevier), 533-542. doi: 10.1016/B978-0-444-59576-8.00040-0

Sivan, A., and Harman, G. E. (1991). Improved rhizosphere competence in a protoplast fusion progeny of Trichoderma harzianum. J. Gen. Microbiol. 137, 23-29. doi: 10.1099/00221287-137-1-23

Testen, A. L., and Miller, S. A. (2018). Carbon source and soil origin shape soil microbiomes and tomato soilborne pathogen populations during anaerobic soil disinfestation. Phytobiomes 2, 138-150. doi: 10.1094/PBIOMES-02-18-0007-R

Testen, A. L., and Miller, S. A. (2019). Anaerobic soil disinfestation to manage soilborne diseases in muck soil vegetable production systems. Plant Dis. 103, 1757-1762. doi: 10.1094/PDIS-09-18-1578-RE

Tripathi, P., Singh, P. C., Mishra, A., Chauhan, P. S., Dwivedi, S., Bais, R. T., et al. (2013). Trichoderma: a potential bioremediator for environmental clean up. Clean Technol. Environ. Policy 15, 541-550. doi: 10.1007/s10098-012-0553-7

Tseng, S.-C., Liu, S.-Y., Yang, H.-H., Lo, C.-T., and Peng, K.-C. (2008). Proteomic study of biocontrol mechanisms of Trichoderma harzianum ETS 323 in response to Rhizoctonia solani. J. Agric. Food Chem. 56, 6914-6922. doi: $10.1021 /$ jf703626j

van Agtmaal, M., van Os, G., Hol, G., Hundscheid, M., Runia, W., Hordijk, C., et al. (2015). Legacy effects of anaerobic soil disinfestation on soil bacterial community composition and production of pathogen-suppressing volatiles. Front. Microbiol. 6:701. doi: 10.3389/fmicb.2015.00701

Vankar, P. S., and Bajpai, D. (2008). Phyto-remediation of chrome-VI of tannery effluent by Trichoderma species. Desalination 222, 255-262. doi: 10.1016/j.desal.2007.01.168

Vinale, F., Flematti, G., Sivasithamparam, K., Lorito, M., Marra, R., Skelton, B. W., et al. (2009). Harzianic acid, an antifungal and plant growth promoting metabolite from Trichoderma harzianum. J. Nat. Prod. 72, 2032-2035. doi: $10.1021 / \mathrm{np} 900548 \mathrm{p}$
Widmer, T. L. (2014). Screening Trichoderma species for biological control activity against Phytophthora ramorum in soil. Biol. Control 79, 43-48. doi: 10.1016/j.biocontrol.2014.08.003

Willyerd, K. T., Li, C., Madden, L. V., Bradley, C. A., Bergstrom, G. C., Sweets, L. E., et al. (2011). Efficacy and stability of integrating fungicide and cultivar resistance to manage Fusarium head blight and deoxynivalenol in wheat. Plant Dis. 96, 957-967. doi: 10.1094/PDIS-09-1 $1-0763$

Worasatit, N., Sivasithamparam, K., Ghisalberti, E. L., and Rowland, C. (1994). Variation in pyrone production, lytic enzymes and control of rhizoctonia root rot of wheat among single-spore isolates of Trichoderma koningii. Mycol. Res. 98, 1357-1363. doi: 10.1016/S0953-7562(09)81 063-0

Xu, X.-M., Jeffries, P., Pautasso, M., and Jeger, M. J. (2011). Combined use of biocontrol agents to manage plant diseases in theory and practice. Phytopathology 101, 1024-1031. doi: 10.1094/PHYTO-08-10-0216

Yan, H., Zhang, B., Li, S., and Zhao, Q. (2010). A formal model for analyzing drug combination effects and its application in TNF- $\alpha$-induced NFKB pathway. BMC Syst. Biol. 4:50. doi: 10.1186/1752-0509-4-50

Zhao, J., Zhou, X., Jiang, A., Fan, J., Lan, T., Zhang, J., et al. (2018). Distinct impacts of reductive soil disinfestation and chemical soil disinfestation on soil fungal communities and memberships. Appl. Microbiol. Biotechnol. 102, 7623-7634. doi: $10.1007 / \mathrm{s} 00253-018-9107-1$

Conflict of Interest: The authors declare that the research was conducted in the absence of any commercial or financial relationships that could be construed as a potential conflict of interest.

Copyright $(\odot 2021$ Khadka and Miller. This is an open-access article distributed under the terms of the Creative Commons Attribution License (CC BY). The use, distribution or reproduction in other forums is permitted, provided the original author(s) and the copyright owner(s) are credited and that the original publication in this journal is cited, in accordance with accepted academic practice. No use, distribution or reproduction is permitted which does not comply with these terms. 